\title{
THE REALIZATION OF "CORPORATE SOCIAL RESPONSIBILITY PROGRAMS" AS A PART OF GCG IN INDONESIAN STATE-OWNED ENTERPRISES (Case Study of PERUM Jasa Tirta I in Malang Regency)
}

\author{
Sri Sulasmiyati \\ Faculty of Administrative Science Universitas Brawijaya Malang \\ Email: sri_su_fia@ub.ac.id
}

\begin{abstract}
ABSTRAK
"Corporate governance seringkali didefinisikan sebagai satu set aturan yang harus dilakukan perusahaan untuk memenuhi hak dan kewajiban terhadap shareholders perusahaan baik pihak internal maupun external yang terdiri dari manajer, kreditur, pemerintah, pekerja dan pihak-pihak yang lain". Salah satu prinsip (GCG) adalah Responsibility, dan ini identik dengan program yang disebut CSR(CSR). Perusahaan-perusahaan milik negara wajib mengimplementasikan prinsip-prinsip GCG tersebut. Program CSR yang dilakukan dengan baik bisa mendukung GCG. Di Indonesia program CSR diatur Pemerintah dalam Peraturan Menteri BUMN. Penelitian ini dilakukan di Perum Jasa Tirta I dengan tujuan untuk mengetahui realisasi program-program CSR apakah sudah sesuai dengan Peraturan Pemerintah. Hasil penelitian menunjukkan bahwa Perum Jasa Tirta I telah merealisasikan program CSR ini dengan baik yang ditunjukkan dengan pengalokasian anggaran untuk CSR per tahun secara maksimal sudah dilaksanakan sesuai ketentuan dan penyaluran program yang direncanakan sudah dilakukan secara efektif.
\end{abstract}

Kata Kunci: GCG, "Corporate Social Responsibility", SOE, "Program Kemitraan dan Bina Lingkungan"

\begin{abstract}
"Corporate governance is as a set of rules that define the relationship between shareholders which is consists of managers, creditors, the government, employees and other internal and external stakeholder in respect to their rights and responsibilities". One of the principles of GCG is Responsibility, which is related to a program, it called CSR(CSR). State-owned enterprises (SOE) as a corporate which is owned by the government, must apply its principles. The implementation of CSR's programs is a one way that could increase GCG condition. The regulation for CSR implementation of SOE in Indonesia has been stated by the government through Ministerial Decrees of BUMN. This research aims to find out how the realization of CSR programs on Perum Jasa Tirta I whether it is same as the government's rule. The research finding that the realizations of PKBL on the Perum Jasa Tirta 1 has been well implemented, annually funds are budgeted realized as much as nearly maximize and distributed effectively.
\end{abstract}

Keywords: GCG, "Corporate Social Responsibility", SOE, "Program Kemitraandan Bina Lingkungan". 


\section{INTRODUCTION}

"Corporate governance can be defined as a set of rules that define the relationship between shareholders which is consists of managers, creditors, the government, employees and other internal and external stakeholder in respect to their rights and responsibilities". In other word, it may say that "Corporate Governance" is the system by which companies are directed and controlled. GCG can happen in the organization by creating the balance between the ownership and control and also among the interests of stakeholders of the firm. "The Organization for Economic Co-operation and Development (OECD)" in 1999 made principles of "corporate governance" which is becomes an international standard for decision maker and their stakeholder's companies from over the world in order to create a GCG. One of the principles is Responsibility, which is related to a program. It is called CSR

Since the 1990s, social and environment awareness has increased significantly in business communities around the world. "The World Business Council on Sustainable Development" (WBCSD, 2000) defines "CSR as a company's commitment in their behavioral ethics and participates in sustainable economic development". CSR is a one form to be responsible to the society. During a decade, CSR has received significant attention in research studies and practices. Many factors became the reasons for companies such as business ethics and corporate awareness of the environmental. The interests of the community in which it operates may also affect the image and success of a company in the long term. CSR is one way to fulfill corporate responsibility to society and its environment. As a "government / state-owned enterprise", PERUM Jasa Tirta I also has several CSR programs as a means to promote GCG principles. Furthermore, this company seems not quite familiar to the society. Based on several reasons that already explained, inspires the researcher to write this research. This paper consists into six parts. The first part is an introduction and followed by reviewing theoretical section. The next part is social setting analysis and research method. After an explanation of result and discussion, the last part of this research is the roots of research findings are concluded and followed by suggestions.
THEORETICAL BACKGROUND AND HYPOTESIS

\section{GCG Theory}

According The OECD (1999:26), Gillan and Starks (1998:10-34) define "corporate governance as the system of laws, rules, and factors that control operations at a company". The objective of "corporate governance" is to create added value to the stakeholders. The "corporate governance" structure requires the distribution of rights and responsibilities among different parties in the corporation, such as, the board, managers, shareholders and other stakeholders, and declares out the rules and procedures for making decisions on corporate matters. By looking the development of term Corporate Governance, in Indonesia, OECD principles transform into guideline which is made by "Komite Nasional Kebijakan Governance" (KNKG) or "the National Committee on Corporate Governance" (NCCG). This guideline is entitled "General Guidelines of Good Corporate Governance Indonesia", which contains guidelines that must be implemented by companies to fulfill their stakeholder rights.

\section{CSR Theory}

Several organizations and experts defined the CSR's definition with several perspectives. Based on the definition of CSR in ISO 26000, CSR is an organisation's responsibility to society and the environment based on their business activities through health, welfare and sustainable development, and complying with local and international regulations (Pojasek, 2011). Morrison (2006) described CSR as a group of related issues, including human rights, human development, and environmental protection. Moreover, Barnea \& Rubin (2010) define CSR as an action taken by companies with respect to their employees, communities and the environment.

There are five interpretations of CSR according to Marrewijk (2003:95-105), which are:

"The first interpretation is CSR "as compliance-driven. The second interpretation is CSR as profit-driven. The third interpretation is CSR as caring. The fourth interpretation is CSR as synergistic, and the fifth and last interpretation is CSR as holistic".

The most established and accepted model of CSR is the "Four-Part Model of Corporate Social Responsibility" as initially 
proposed by Archie Carroll (1979) (Crane, Andrew and Matten, Dirk. 2007: 25-30). Carrol regards CSR as "a multi-layered concept", which can be differentiated into four inter-related aspects - economic, legal, ethical, and philanthropic responsibilities.

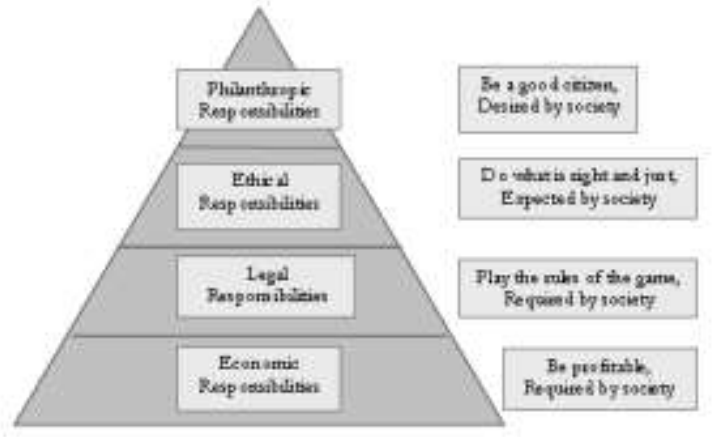

Figure 1. The Pyramid of CSR

Source: Carroll (1989:31; 1991:42) in Davidsson

(2004: 42)

\section{Government/State-Owned Theory}

According to the "OECD Guidelines on

Corporate Governance of State-owned Enterprises", "SOE refers to enterprises where the state has significant control, through full, majority, or significant minority ownership" (OECD, 2005). The term SOE also refers to business entities established by central and local governments, and whose supervisory officials are from the government. "The Guidelines on Corporate Governance of State-owned Enterprises" (OECD, 2005) consists five principles, those are: "Ensuring an Effective Legal and Regulatory Framework for StateOwned Enterprises, The State Acting as an Owner, Equitable Treatment of Shareholders, Relations with Stakeholders and Transparency and Disclosure".

\section{Stakeholders Theory}

Carroll in Crane and Dirk (2007:55) stated that "the word stakeholder derives from the word stake and refers to groups or individuals who have a stake, an interest or a claim, in the operations and decisions of a company". The stakeholders included shareholders, employees, customers, suppliers, lenders and society (Freeman \& Reed, 1993). According to Rhenman (1967) in Davidsson (2004:44) “an organisation's stakeholders are those individuals or groups who depend on the company to realise their personal goals and on whom the company is dependent for its existence". Freeman's \& Reed's (1993) wider definition of stakeholders aims at any identifiable group or individual who can affect or is affected by the company's operations direct or indirectly, accordingly covering all different parties or groups which mentioned above. The stakeholders of related to an organisation are illustrated in this figure.

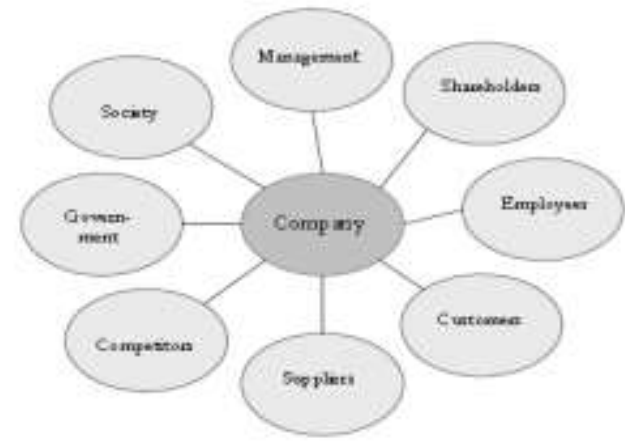

Figure 2.A company's stakeholders Source: Rhenman (1967:36) in Davidsson (2004:45)

\section{SOCIAL SETTING ANALYSIS}

\section{Indonesia Government / State-Owned Enterprises}

"The Government Regulation No. 3 of 1983 define State companies or State-Owned Enterprise is a legal entity corporation with capital owned, either in part or in whole, by the State". Furthermore as mentioned in "Section1 of Act No.19 of 2003 on state-owned enterprises, SOEs that are entirely or majority capital owned by the state through direct investment from the wealth". There are some changes and improvements of the practices of SOEs. According to "Law No. 9of 1969; the Government Regulation No. 3 of 1983 and the Government Regulation No. 6 of 2000", there are three types of state-owned enterprises, namely "(1) Company Bureau (in Indonesian said Perusahaan Jawatan/Perjan), (2) Public Company (in Indonesian said Perusahaan Umum/Perum), and (3) Limited Liability Company (in Indonesian said Perusahaan Perseroan/Persero)". However, with the release of the latest "Law on State-owned Enterprises, the Law No. 19 of 2003 on state-owned enterprises", State enterprises only divided into two, namely Perum and Persero, while the existence of Perjan was deleted.

\section{CSR in Indonesia}

In recent years, trend to implement CSR in Indonesia is getting increase. Many companies try to catch its benefits by doing the CSR programs.Based on "The Decree of the 
Coordinator Minister of the State-Owned Enterprises No. PER-05/MBU/2007 dated 27 April 2007"; all of "Government / state-owned enterprises" must implement CSR programs provided to the communities around them. In addition, Indonesia has become the first country in the world to require the implementation of CSR formally in law.

\section{Perum Jasa Tirta I}

According to the "Decree of Minister of State-Owned Enterprise KEP.100/MBU/2002”, Perum Jasa Tirta 1 classified as "State-Owned Enterprise infrastructure' business sector". It is one of SOEs which have business activities are organized forpublic services of water resources and quality and in fulfilling lives for many peoplesufficiently.

\section{RESEARCH METHOD}

This research used qualitative method. The data collected to be analyzed through data analysis process of Miles and Huberman Model (1994, p. 15). This research takes place in PERUM Jasa Tirta I in Malang City which is conducted on 2013. Source of the data consist of two sources, which are primary data and secondary data. The informants of this research are the General Manager of Public Relation of Perum Jasa Tirta 1 and the Head of PKBL of Perum Jasa Tirta I.

\section{RESULTS AND DISCUSSION}

Implementation of CSR for SOEs in Indonesia has been regulated in "Ministerial Decrees: BUMN No. Kep-236/MBU/2003 and Per-05/MBU/2007 on Partnership and Community Development Programs (PKBL)". This program divided into two different program, which are called "Small Business Partnership Program" (in bahasa said "Program Kemitraan Usaha Kecil") and "Community Development Program" (in bahasaIndonesia is "Program Bina Lingkungan"). As same as other purpose of private companies, the SOE's is also gaining maximum profit. In order to increase it, despite of giving loan for small business in the name of PKBL, the SOE could get the profit from it. Another part of SOEs in this program is providing guidance and support to small business, cooperation and community actively.

Furthermore, according to SOEs Minister'regulation, the sources of PKBL funding comes from corporate net income allowance for profit after tax of $2 \%$ for a maximum deducted for the "Partnership or the Community Development Program". This is consistent with "Ministry Regulation BUMN No. PER-05/MBU/2007 April 27, 2007”, regarding the funding sources of "small business partnerships and community development program" which is as follows:

1. For "Small Business Partnership Program" (in Indonesia said "Program Kemitraan Usaha Kecil"), the source of the fund comes from allowanceof $2 \%$ for profit after tax of a maximum, the result of administrative services and the bank reduced interest expense.

2. In addition, 'Community Development Program" (in Indonesia said "Program Bina Lingkungan"),the sources of funds come from $2 \%$ of maximum retained earnings and yields after deducting operating expenses.

In order to reduce unemployment and increase business opportunities, PerumJasaTirta I as are required to guide small business to become an independent small business as mandated by "Act 19 of 2003 on state-owned enterprises". In addition to fostering small business, the company can also set aside part of their profits for the purposes of guidance through the "Partnership and Community Development Program (PKBL)". In relation with the development of small businesses which are guided, the company is expected to provide effects such as rising standards of living and encourage partnerships between companies and small businesses.

In brief, the development of CSR through the "Partnership and Community Development Program (PKBL)"PerumJasaTirta I are as follows:

1. Since 1993 up to 2010 PerumJasaTirta I Rp.5.126.375.555 spent of "partnership funds", for working capital loans to small industries and cooperatives, educating and training costs assisted partners conducted by universities / LPPM Rp. 840065 000, -. The number of partners who have fostered built from 1993 to 2010 as many as 1456 target partners.

2. PKBL funds procedure has been set according to the "Decree of Directors" which Partners Perum Jasa Tirta 1 to small economy citizens with a wide range of businesses including: industrial sectors (domestic handicraft industry, clothing industry and the food industry), trade (essential commodities, selling food and 
beverages), agriculture and the service sector and other small-scale business with simple management.

3. Since the Year 2011 PerumJasaTirta 1 doing some collaboration with the local village government to be able to select and give socialization about the program, to the people whose need additional capital for her/his own business.

4. Theneeded to legislate the rule to eliminate bad debts, which is caused by several reason such as the target partner had died, the serious sickness less likely to recover, and the business suffered bankruptcy / close.

The grants will be provided around the work area Perum Jasa Tirta 1 in East Java and Central Java, namely:

1. East Java in Malang, Kab. Malang, Batu, Kab. Kediri, Kab. Mojokerto, Kab. Tulungagung, Kab. Blitar, KabTrenggalek, Kab. Jombang, Kab. Madiun, Kab. Bojonegoro, Kab. Lamongan, Kab. Ngawi.

2. Central Java in the KabupatenWonogiri, and Kartasura.

In distributing loans for the "partnership program funds", the following steps are as follows:

1. The first thing to do before distributing funds, the internal unit of PerumJasaTirta 1 coordinate with related agencies, namely the village where targeted partners guided, by disseminating information to small businesses about the partnership program to obtain the intended target.

2. Prospective partners are required to make a proposal by filling some forms that have been set by Perum Jasa Tirta 1. Then PJT 1 selects and evaluates the proposals that have been submitted by the auxiliaries' partners.

3. Furthermore PJT 1 conducted a field observation to observe the real condition of the target of potential partners to determine the amount of loan to be granted.

4. The last step is the PJT 1 gives a decision to be published in the Decree of the Board. So based on the Decree of the Board, PKBL managers will be doing the agreement / contract as an attachment to the target partner.

Gfrerer and Silvyani (2010) stated, "Ministerial Decrees describe the frame of CSR activities but do not provide a universal definition for the term CSR". So far CSR activities on SOE are understood as "Partnership and Community Development Programs
(PKBL)". "Partnership Development Programs as Loan Programs and Community Development Programs as Grant Programs".

The objectives for "Partnership Development Programs" are companies want to give something back to communities where the companies are working in. CSR contributions are direct contributions to the communities and are not considered as part of the national regional development Programs. Companies also want to show their appreciation to the communities, to develop their economic environment respectively to create a win-win situation with communities and to set up sustainable cooperation with communities. In the other hand, "Community Development Programs" are grants for education, health, environment, infrastructure, public services (schools, water supply, waste water, market places, etc) and disaster.

This below tables shows the amount of the development of effectiveness and collectability of partnerships loans from 2008 to 2011 to small businesses in general.

Tabel 1

The development of effectivity and collectibility of loans

\begin{tabular}{|c|c|c|c|c|}
\hline Year & $\begin{array}{c}\text { Effectiveness } \\
\text { \% }\end{array}$ & $\begin{array}{c}\text { Scor } \\
\text { e }\end{array}$ & $\begin{array}{c}\text { Colectability } \\
\text { \% }\end{array}$ & $\begin{array}{c}\text { Sco } \\
\text { re }\end{array}$ \\
\hline 2008 & 95,69 & 3 & 59,68 & 2 \\
\hline 2009 & 96,51 & 3 & 69,91 & 2 \\
\hline 2010 & 91,00 & 3 & 92,97 & 3 \\
\hline 2011 & 95,01 & 3 & 96,34 & 3 \\
\hline
\end{tabular}

Source: PKBL Financial Statement 2011

The list of assessment refund rate partnership program is divided into several scores based on the percentage of loan repayment. If thepercentage isbelow 10score is" $0 "$, if the percentage is 10 to 40 percent the scoreis "1", the percentage is 40 to 70 the scoreis"2", and the percentage isabove70 thenthe scoreis "3". " 3 " is the highest score of this level.

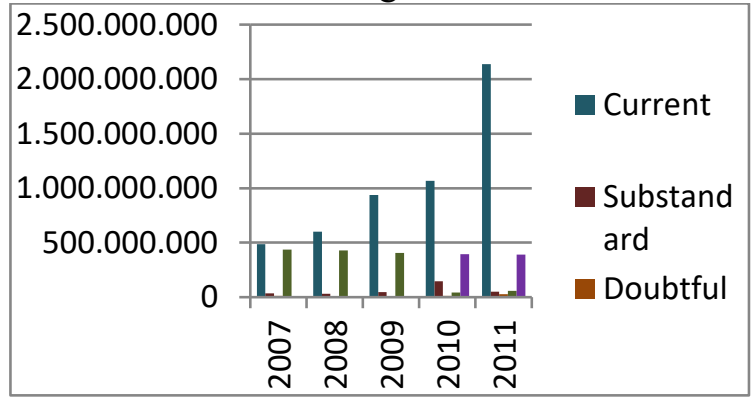

Figure 3. The Quality of Loans Diagram Source: data proceed by researcher (2013) 
By implementing CSR programs through PKBL, Perum Jasa Tirta I has been recognize to the society as a good and caring company. It corresponds with the purpose of the GCG motives which are compliance-driven, profit-driven, caring, synergistic and holistic, which is fully integrated in every aspect of the company, contribute to the quality and continuation of life to the society.

\section{CONCLUSION AND REMARK \\ Conclusion}

Based on discussions in previous chapters, it can be concluded as follows:

"The Partnership Program to Small Enterprises and Community Development Program", through "the Minister of State Enterprises No.: Per-05/MBU/2007 date 27 April 2007 on state Partnership to Small Business and Community Development Program" consists basically of two types of program, a program of strengthening small businesses through the provision of revolving loan funds and assistance (called "Partnership Program") and the social conditions of the community empowerment program (called the "Community Development Program"). By looking this explanation we could be conclude that PKBL is the CSR program on SOEs.

The source of funding for CSR program is also arranged in that regulation. It is derived from $2 \%$ of the maximum allowance for profit after tax of the company. By looking at the data about the fund distribution of PKBL on the table we could know that the realization of corporate social responsibility program in the Perum Jasa Tirta 1 annually funds are budgeted realized as much as nearly maximize and distributed effectively.

GCG is a system and a set of rules which is regulate stakeholder's relationship. Through CSR Programs, it forces company to pay attention and implement not only the laws but also their responsibilities to the communities and the environment. Implementation of CSR is one application of GCG principles related to corporate responsibility to the public.

\section{Remark}

CSR as a form of company's care to society is to provide guidance in the form of the evaluation, distribution, billing, training, monitoring, and promotion, administrative and financial functions to the community. If the program can be implemented as quickly as possible and managed optimally, then the existence of the partnership program to reach small business owners (partners assisted) more broadly, so that it's multiplier effect can spread nationally. It is time for companies to increase awareness of the surrounding community as a form of corporate social responsibility to the public, so that the company can maintain a sustainable company. Hopefully CSR program can be arranged both professionally and transparently. In result, CSR will give more benefit for economic empowerment society in the local community, and will share benefits to the wider community ultimately.

\section{REFERENCES}

Andayani, Wuryan; Atmini, Sari; Sadewo, Dede; Wangi, James Kamau M. 2008.Corporate Social responsibility, Good Corporate Governance and The Intellectual Property: An External Strategy of The Management to Increase The Company's Value.National Conference on Management Research, Makasar.

Carroll, Archie B. July-August 1991. The Pyramid of Corporate Social Responsibility: Toward the Moral Management of Organizational Stakeholders. Business Horizons.

Centidamar, Dilek. Kristoffer Husoy. 2007. Corporate social responsibility, practices and Environmentally Responsible Behaviour: The case of The United Nations Global Compact. Journal of Business Ethics (2007) 76:163-176

CLSA, Media Release: CLSA Launches Corporate Governance Watch 2007, (25 September 2007) <http://www.calyon.com/news/corporateinvestment-bank/press-releases200774/\$File/CLSA\%20Launches\%20Corp orate\%20Governance\%20Watch\%202007_2 5092007_FINAL_.pdf>

Crane, Andrew and Matten, Dirk. 2007. Business Ethics: Managing Corporate Citizenship and Sustainability in the Age of Globalization. New York. Oxford University Press

Davidsson, Linda. 2004. Corporate Social Responsibility (CSR) Activities of Swedish Multinational Companies (MNCs) 
Contributing to Economic and Social Development in the Argentinean Society. LinkopingsUniversitet Argentina

Dumairy,

1997.Perekonomian Indonesia.Jakarta :PenerbitErlangga.

EDB Singapore, Perceptions of Corporate Governance Standards, <http://www.sedb.com/edb/sg/en_uk/index/ why_singapore/singapore_rankings.html>

Falck, Oliver and Stephan Heblich. 2007. Corporate Social Responsibility: Doing Well By Doing Good. Business Horizons 50. p. 247-254.

FCGI. 2006. What is Corporate Governance.FCGI Publication

Freeman, R. Edward; Reed, David L. 1983. Stockholders and Stakeholders: A new perspective on Corporate Governance. California Management Review, Vol. 25 Issue 3, p88-106.

Gfrerer, Margareth,. and Meta Silvyani.2010. Sustainability of CSR Activities of Indonesian State-Owned Enterprises.The 3rd GRI Global Conference on Sustainability and Transparency, Amsterdam.

Gillis, T. \& Spring, N. 2001. Doing good is good for business. Communication World.18(6) October/November pp. 23-26.

Gillan, S.L., Starks, L.T., 1998. A survey of shareholder activism: motivation and empirical evidence.Contemporary Finance Digest 2 (3). 10-34

Jamali, Dima. Asem M. Safieddine and Myriam Rabbath. 2008. Corporate Governance and Corporate Social Responsibility Synergies and Interrelationships. Journal compilation. Blackwell Publishing Ltd.

Koestoer, Yanti. 2007. Mixed Perceptions of Corporate Social Responsibility: Experiences of Indonesia. Washington, DC USA. Center for International Private Enterprise,

Lattemann, Christoph. Marc Fetscherin, Ilan Alon, Shaomin Li, and Anna-Maria Schneider. 2009. CSR Communication Intensity in Chinese and Indian Multinational Companies. Corporate Governance: An International Review, 17(4): 426-442
Marrewijk, M. van. 2003. Concepts and Definitions of CSR and Corporate

Sustainability: Between Agency and Communion. Journal of Business Ethics.44 pp. 95-105.

Miles, M. B. \& Huberman, A. M. (1984).Qualitative Data Analysis: A Sourcebook of New Methods.California; SAGE publications Inc.

Miles, Mathew B and A. Michael Huberman. 1994. Qualitative Data Analysis an Expanded Sourcebook $2^{\text {nd }}$ Edition. London. Sage Publications

Moleong, Lexy J., 2007. MetodologiPenelitianKualitatif. Bandung: PT. RemajaRosdaKarya.

National Committee on Governance, Indonesia's Code of Good Corporate Governance. 2006.<http://www.governanceindonesia.com/donlot/Pedoman\%20GCG\%2 0Indonesia\%202006.pdf>

Organisation for Economic Co-Operation and Development. 2005.OECD Guidelineson Corporate Governance of State-owned Enterprises. France. OECD Pubishing.

Organization for Economic Cooperation and Development. 1999. OECD Principles of Corporate Governance.France. OECD Pubishing

Sparkes, Russell. 2003. From Corporate Governance to Corporate Responsibility: The Changing Boardroom Agenda. Ivey Business Journal.

Stoker, G. 1998. Governance as Theory: Five Propositions. International Social ScienceJournal, Vol. 50, No. 1: 17-28.

Suharto, Edi. 2008. Menggagas Standar Audit Program CSR/Initiating Audit Standard of CSR Program. 6th Round Table Discussion "Menggagas Standar Audit Program CSR: Implementasi UU Perseroan Terbatas, Asosiasi Auditor Internal (AAI),Financial Club Jakarta, 27 Maret 2008.

Suharto, Edi. 2008. "Corporate Social Responsibility: What is and Benefit for Corporate" makalah yang disajikanpada Seminar Dua Hari, Corporate Social Responsibility: Strategy, Management and 
Leadership, Intipesan, Hotel Aryaduta Jakarta 13-14 Februari.

Vallabhaneni, S. Rao. 2008. Corporate Management, Governance and Ethics Best Practices.John Wiley \& Sons, Inc. New Jersey.

Vidaver-Cohen, D. \& Altman, B. W. 2000.Concluding Remarks - Corporate Citizenship in the New Millennium:

Foundation for an Architecture of Excellence.Business and Society Review.105(1) pp. 145-168.

WBCSD: 2000, 'Corporate Social Responsibility: Making Good Business Sense' [online]. URL: http://www.wbcsd.org/includes/getTarget .asp?type $=\mathrm{d} \& \mathrm{id}=\mathrm{MzE} 0$. 